\title{
Differential expression of IGF-binding protein-3 in normal and malignant colon and its influence on apoptosis
}

\author{
P J Jenkins, S Khalaf, W Ogunkolade, K McCarthy, T David, R E Hands ${ }^{1}$, \\ $D$ Davies $^{2}$ and S A Bustin ${ }^{1}$
}

\begin{abstract}
Department of Endocrinology, William Harvey Research Institute, Barts and the London Queen Mary's School of Dentistry, John Vane Building, Charterhouse Square, London EC1M 6BQ, UK

${ }^{1}$ Cancer Research UK, 61 Lincoln's Inn Fields, London WC2A 3PX, UK

2Department of Academic Surgery, Barts and the London Queen Mary's School of Dentistry, University of London, Turner Street, London E1 2AD, UK
\end{abstract}

(Requests for offprints should be addressed to P J Jenkins at the Department of Endocrinology, St Bartholomew's Hospital, West Smithfield, London EC1A 7BE, UK; Email: P.J.Jenkins@qmul.ac.uk)

\begin{abstract}
IGF-binding protein-3 (IGFBP-3) has been reported to exert a protective influence on the pathogenesis of colorectal cancer. This may reflect its modulation of IGF-I bioactivity as well as IGFI-independent effects on cell proliferation and apoptosis. Although local expression of IGF-I in the colon is increasingly recognised as having important regulatory consequences, the role of locally expressed IGFBP-3 remains unknown. The aims of the present study were: (i) to quantify and localise the expression of IGFBP-3 in human normal and malignant colon; (ii) to relate this expression to that of other components of the IGF-I axis; and (iii) to investigate the effects of IGFBP3 on colonic epithelial cell proliferation and apoptosis. RNA was extracted from 46 paired samples of normal and malignant colonic tissue. IGFBP-3, IGF-I, IGF-I receptor and GH receptor mRNA levels were quantified using real-time RT-PCR. Laser-capture microdissection of the same samples was used to isolate mRNA from epithelium and stromal components and localise mRNA expression. Expression was confirmed at a protein level by immunohistochemistry. Human colorectal cancer HT-29 and CaCo-2 cells were cultured with IGFBP-3 $(200 \mathrm{ng} / \mathrm{ml}),+/-$ IGF-I $(20 \mathrm{ng} / \mathrm{ml}),+1-$ sodium butyrate $(5 \mathrm{mM})$. Cell number was assessed by an MTS assay (a modification of the MTT assay), and apoptosis assessed by cell morphology and FACS analysis using both annexin and propidium iodide staining. UO146, a MAP kinase inhibitor, and wortmannin, an inhibitor of the phosphatidylinositol 3-kinase (PI-3K) pathway, were used to determine the contribution of these signalling pathways on the effects of IGFBP-3. IGFBP-3 mRNA was detected in all samples (mean copy number/ $\mu \mathrm{g}$ total RNA in normal colon, $2.6 \times 10^{6}$ compared with $1.3 \times 10^{7}$ in the cancers; $P<0.0001$ ). Immunohistochemistry confirmed the expression and showed it to be equally distributed between epithelial and stromal components in normal tissue, but to be mainly restricted to the stromal component of malignant tissue. This differential expression was confirmed by RTPCR of RNA from laser-capture microdissected samples. IGF-I mRNA was detected in 31 samples of normal colon; mean IGFBP-3 copy number was higher in the IGF-I-positive samples compared with IGF-I-negative samples. IGFBP-3 on its own induced apoptosis in HT-29 cells $(P<0.001)$. Coincubation of $200 \mathrm{ng} / \mathrm{ml}$ IGFBP-3 with butyrate $(5 \mathrm{mM})$ resulted in the potentiation of its apoptosis $(P<0.0001)$, which was not rescued by co-incubation with IGF-I $(P<0.0001)$. The addition of U0126 caused a decrease in cell number and increased the effects of IGFBP-3. IGFBP-3 is differentially expressed between stromal and epithelial components of normal and malignant colon, which may reflect its pro-apoptotic, IGF-I-independent effect on colonic epithelial cells. These effects are mediated in part by the PI-3K pathway in contrast to the MAP kinase pathway used by IGF-I.
\end{abstract}

Endocrine-Related Cancer (2005) 12 891-901 


\section{Introduction}

Circulating insulin-like growth factor binding protein 3 (IGFBP-3) and insulin-like growth factor-I (IGF-I) are primarily hepatic-derived peptides that modulate cellular growth, differentiation and apoptotic responses. While serum levels of IGF-I, which are regulated by growth hormone $(\mathrm{GH})$, are generally considered to be a positive risk factor for the development of colorectal cancer, the role of IGFBP-3 appears less clear. Some studies suggest it exerts a protective effect (Ma et al. 1999, Giovannucci et al. 2000) while others do not support such a role (Renehan et al. 2004). In addition to modulating the bioavailability of IGF-I, IGFBP-3 is also an important mediator of growth inhibitory agents, such as retinoic acid, vitamin $\mathrm{D}$, transforming growth factor- $\beta$, anti-oestrogens, tumour necrosis factor- $\alpha$ and $p 53$, independently of the IGF signalling system (Gill et al. 1997, Oh 1997, Baxter et al. 2000). Although IGF-I-independent growth inhibition by IGFBP-3 has been reported in colonic cell lines, a regulatory role in the colon remains uncertain. Positive immunostaining for IGFBP-3 protein has previously been reported in colonic cancers and it appears to be differentially expressed along the colonic crypt (Michell et al. 1997, Williams et al. 2000, Miraki-Moud et al. 2001). However, immunohistochemical staining cannot distinguish circulating IGFBP-3 protein from local paracrine/autocrine expression. This is particularly relevant given recent work emphasising the importance of autocrine and paracrine actions of IGF-I in normal growth and development (Le Roith et al. 2001), effects which we have also demonstrated in colorectal tumourigenesis and tumour neovascularisation (Bustin et al. 2002). Furthermore, the functional relevance of any expression of IGFBP-3 in the colon is also unknown as is its relationship to components of the IGF-I axis.

Dietary factors appear to play an important role in both the development and prevention of colorectal cancer. One such factor, sodium butyrate, has potent in vitro anti-tumourigenic effects on many colon cancer cell lines, including inhibition of growth and promotion of apoptosis. A recent report has indicated a significant increase in apoptosis accompanying the induction of IGFBP-3 in a colorectal adenoma cell line by butyrate (Collard et al. 2003). IGFBP-3 by itself has no effect on the viability of these cells but initiates an increase in p53-dependent apoptosis to previously gamma-irradiated cells (Williams et al. 2000). Interestingly, in mammary epithelial cells these pro-apoptotic effects of IGFBP-3 are limited to cancerous cells, which may point to an important mechanism for growth inhibition by IGFBP-3 in cancer (McCaig et al. 2002). Altogether these observations suggest that IGFBP-3 may be a major downstream effector of growth inhibitory and apoptosis-inducing agents in cancers. As there have been no studies comparing the simultaneous expression of IGFBP-3 in normal and malignant colonic tissue, the aims of this study were first to quantify and localise expression of IGFBP-3 in normal and malignant human colon tissue, secondly to relate this expression to that of IGF-I and its receptor (IGF-IR) as well as the GH receptor (GH-R), thirdly to determine any association between this expression and the clinical phenotype of colon cancer, and fourthly to determine the IGF-I-independent effects of IGFBP-3 on colon epithelial cell proliferation and apoptosis.

\section{Materials and methods}

\section{Patient samples}

This study was approved by the Local Research Ethics Committee of the East London and City Health Authority and all patients gave informed consent. Paired samples of normal and malignant colon were taken from 46 consecutive patients undergoing surgery for colorectal carcinoma. Sixteen cancers were located in the proximal colon, and 30 distal to the splenic flexure.

\section{RT-PCR}

RNA was extracted from the samples as previously described (Bustin et al. 1999) except that the samples were homogenised in $2 \mathrm{ml}$ cryotubes using a bead mill (Glen Creston Ltd, Stanmore, Middx, UK), with three steel beads per $0.5 \mathrm{ml}$ lysis buffer. RNA quality and quantity was assessed, in triplicate, using RNA LabChips together with an Agilent 2100 Bioanalyser (Agilent Technologies, Waldbronn, Germany). Primers and probes were newly designed using Primer Express software (ABI, Warrington, Cheshire, UK) (Table 1). Real-time RT-PCR assays were performed according to the criteria previously described (Bustin 2000). Reactions were carried out and results recorded and analysed using the ABI 7700 Prism Sequence detection system. mRNA levels were quantified relative to amplicon-specific standard curves (Bustin 2000). Copy numbers were normalised relative to total RNA concentration and expressed as copy numbers $/ \mu \mathrm{g}$ RNA. All serial dilutions were carried out in duplicate. The reactions to generate standard curves were repeated twice, each time in triplicate. All clinical samples were tested in triplicate and the average 
Table 1 Primers and probes for real time RT-PCR mRNA quantification of IGFBP-3, IGF-I, IGF-IR and GH-R genes

\begin{tabular}{|c|c|c|}
\hline Target gene & Primers and probes $\left(5^{\prime}-3^{\prime}\right)$ & Amplicon size (bp) \\
\hline \multirow[t]{3}{*}{ IGFBP-3 } & F: AGCACAGATACCCAGAACTTCTCC & 76 \\
\hline & R: TCCATTTCTCTACGGCAGGG & \\
\hline & P: CATATTCTGTCTCCCGCTTGGACTCGG & \\
\hline \multirow[t]{3}{*}{ IGF-I } & F: CTTCAGTTCGTGTGTGGAGACAG & 75 \\
\hline & R: CGCCCTCCGACTGCTG & \\
\hline & P: TTTTATTTCAACAAGCCCACAGGGTATGGC & \\
\hline \multirow[t]{3}{*}{ IGF-IR } & F: CTCCTGTTTCTCTCCGCCG & 84 \\
\hline & R: ATAGTCGTTGCGGATGTCGAT & \\
\hline & P: TGGCCCGCAGATTTCTCCACTCGT & \\
\hline \multirow[t]{3}{*}{$\mathrm{GH}-\mathrm{R}$} & F: TTTGGAATATTTGGGCTAACAGTG & 84 \\
\hline & R: TCAССТССТСТААТTTTССTTССTT & \\
\hline & P: AAGGATTAAAATGCTGATTCTGCCCCCAGT & \\
\hline
\end{tabular}

$\mathrm{F}$, forward, $\mathrm{R}$, reverse primers; $\mathrm{P}$, Taqman probe.

value of the triplicates was used for quantification. Two no-template controls were included with every amplification run; one was prepared before opening all the tubes and dispensing the various reagents, the other at the end of the experiment.

\section{Laser-capture microdissection and RNA preparation}

An empty, labelled cryomould was placed on dry ice for $1 \mathrm{~min}$. The bottom of the cryomould was then lightly covered with OCT medium (Cryo-M-Bed; Bright Instruments, Huntingdon, Cambridgeshire, UK) and the tissue was placed against the bottom of the cryomould. Additional OCT medium was added to the cryomould until the tissue was completely covered and left to harden on dry ice. Blocks were placed into individual Petri dishes and stored at $-80^{\circ} \mathrm{C}$ until required. Fresh frozen blocks were left to pre-cool for $15-20 \mathrm{~min}$ in the cryostat $\left(-20^{\circ} \mathrm{C}\right)$ to avoid shattering of the sections. The cryostat was cleaned thoroughly (RNase-free) before sectioning and blades were changed for each block to avoid cross contamination. Seven-micron thick sections were mounted onto specialised membrane-covered slides (PALM Technologies, Bernried, Germany) and immediately fixed in icecold $70 \%$ ethanol. The sections were then dehydrated in an ethanol series (75, 95 and $100 \%$ on ice), xylene treated and left to air dry briefly. Sections were laser dissected within $1 \mathrm{~h}$. Slides were observed using a Zeiss Axiovert $200 \mathrm{M}$ inverted laser-capture microscope and visualised on a monitor using the PALM RoboSoftware. Individual crypts were identified (minimum of 200) and cut out along pre-drawn lines (hand drawn circles around the crypts) using the laser. Then using a separate catapult function (LPC), the individual crypts were catapulted up into specialised PALM adhesive caps. Approximately equal areas of stromal tissue and crypts were laser dissected and collected separately. The individual caps were then placed onto RNase-free Eppendorf tubes and tissue was immediately lysed with lysis buffer. RNA was extracted using the RNeasy Microkit (Qiagen) and microdissection protocol. Both a poly-A RNA carrier and an equal volume of $70 \%$ ethanol were added to the lysate and mixed thoroughly. The lysate was transferred to a MinElute spin column and centrifuged at $8000 \mathrm{~g}$ for $15 \mathrm{~s}$. The column was washed with buffer, centrifuged and the bound RNA was DNase treated (15 min at room temperature). The column was washed again with buffer and $80 \%$ ethanol and centrifuged at $8000 \mathrm{~g}$ for $2 \mathrm{~min}$. The column was centrifuged for a further $5 \mathrm{~min}$ to allow the silica gel membrane to dry. To elute the RNA, $25 \mu$ l elution buffer were put directly onto the silica gel membrane and left to incubate for $10 \mathrm{~min}$ at room temperature. The sample was then spun at $8000 \mathrm{~g}$ for $1 \mathrm{~min}$; this step was repeated to maximise yield. All samples were put at $-70^{\circ} \mathrm{C}$ for long-term storage.

\section{Immunocytochemistry}

Four-micron sections were cut from paraffinembedded blocks of the cancers and paired normal colonic tissue, including all those used for laser microdissection, and deparaffinised by standard techniques. For antigen retrieval, sections were microwave treated under pressure for $4 \mathrm{~min}$ at $900 \mathrm{~W}$ in preheated $0.01 \mathrm{M}$ citrate buffer $\mathrm{pH}$ 6.0. Sections were then blocked with horse serum for $5 \mathrm{~min}$ to block nonspecific binding before incubating with the primary rabbit anti-human affinity-purified polyclonal IGFBP-3 antibody (GroPep, Adelaide, Australia) at a 1/50 
dilution for $90 \mathrm{~min}$ at $37^{\circ} \mathrm{C}$. After washing off the primary antibody in Tris-buffered saline, slides were incubated with a secondary biotinylated antibody (Vectastain Universal Elite ABC kit; Vector Labs, Peterborough, Cambs, UK) at room temperature for $30 \mathrm{~min}$ and rinsed again in Tris-buffered saline. A tertiary peroxidase-labelled avidin was subsequently applied at room temperature for $20 \mathrm{~min}$ before the sections were visualised both with a Tyramide signal amplification fluorescein system (NEN Life Science Products, Boston, MA, USA) for $5 \mathrm{~min}$ and with activated 3,3'-diaminobenzidene tetrahydrochloride solution (Kentec DAB Tablets 4170; Biostat, Stockport, UK) for $10 \mathrm{~min}$. Sections of human liver were used as a positive control in each run. Specificity of the antibody was confirmed by the absence of immunoreactivity after pre-incubation of the antibody with IGFBP-3. Assessment was performed in a blinded manner and a score determined in both the epithelial cells and the stroma of the intensity of staining $(1=$ absent $/$ weak, $2=$ moderate, or $3=$ strong $)$ and the percentage of positive staining cells $(1=$ less than $5 \%$, $2=5-50 \%$, or $3=$ more than $50 \%$ ). A total score (maximum of 6) was then generated for the epithelial and stromal component of each section.

\section{Tissue culture}

Two human colorectal carcinoma cell lines, HT-29 and CaCo-2 (American Type Culture Collection, ATCC), were grown to near confluence in $150 \mathrm{ml}$ flasks in $5 \%$ $\mathrm{CO}_{2}$ at $37^{\circ} \mathrm{C}$ in McCoy's modified medium containing $10 \%$ foetal calf serum, $1 \%$ glutamine, $25 \mathrm{mM}$ HEPES buffer, $1 \%$ penicillin and streptomycin. Cells were used between passage 14 and 40 . Prior to experiments, cells were trypsinised, washed and incubated in serum-free medium for $24 \mathrm{~h}$. The serum-free medium was then replaced with that containing the experimental stimuli. Negative controls were serum-free medium only and positive controls were $20 \mathrm{ng} / \mathrm{ml}$ IGF-I only (gift from Pfizer, UK).

Assessment of proliferation was carried out in 96-well plates at an initial cell density of $1 \times 10^{4}$ cells/ well. The final concentration of IGFBP-3 (GroPep) investigated was $200 \mathrm{ng} / \mathrm{ml}(4 \mathrm{nM})$, with and without IGF-I $(20 \mathrm{ng} / \mathrm{ml})$. Sodium butyrate $(5 \mathrm{mM})$ was used as a known apoptotic agent. The final volume was $100 \mu \mathrm{l} /$ well. Each stimulus was assessed in 12 separate wells and each experiment repeated on at least three occasions. Cell number was assessed after 24 and $48 \mathrm{~h}$ by the MTS assay (a modification of the MTT assay - CellTiter 96 Aqueous One Solution Cell Proliferation Assay; Promega) and calculated as a proportion of that obtained from medium only. Results are expressed as means \pm s.E.M. of three experiments.

Assessment of apoptosis was performed on cells incubated in T25 flasks at the same initial density $\left(10^{5}\right.$ cells $\left./ \mathrm{ml}\right)$ with and without the addition of IGFBP-3 (200 ng/ml), IGF-I $(20 \mathrm{ng} / \mathrm{ml})$ and sodium butyrate $(5 \mathrm{mM})$. Apoptosis was assessed using FACS analysis at $24 \mathrm{~h}$ by annexin staining and at $48 \mathrm{~h}$ by propidium iodide (PI). Results are expressed as means \pm s.E.M. of three experiments. For annexin staining, cells were trypsinised and re-suspended in $1 \mathrm{ml}$ annexin-binding buffer (Pharmingen) to which were added $5 \mu$ l Annexin V-FITC $(2.5 \mu \mathrm{g} / \mathrm{ml}$; Pharmingen). After incubation in the dark at room temperature for $15 \mathrm{~min}, 50 \mu \mathrm{l} \mathrm{PI}(50 \mu \mathrm{g} / \mathrm{ml}$; Sigma) were added to discriminate dead cells and the samples were analysed on a FACS Calibur (Becton Dickinson) (Vermes et al. 1995). For sub-G1 analysis, cells were trypsinised, washed in PBS and fixed in cold $70 \%$ alcohol for at least $30 \mathrm{~min}$. After washing twice in phosphatecitrate buffer, cells were treated with $50 \mu \mathrm{l}$ RNAse A $(100 \mathrm{mg} / \mathrm{ml}$; Sigma $)$ and $250 \mu \mathrm{l}$ PI $(50 \mu \mathrm{l} / \mathrm{ml})$ and analysed on a FACS Calibur with appropriate pulse processing to exclude cell doublets (Gong et al. 1994).

\section{Inhibition of MAP kinase and phosphatidylinositol 3 (PI3)/AKT signalling}

The effects of UO126 (Sigma), an inhibitor of the MAP kinase pathway, acting at the level of ERK-1 and ERK-2 and wortmannin (Sigma), a selective PI3 kinase inhibitor, were tested on HT-29 cells. Cells were grown as described above with cell number measured after $48 \mathrm{~h}$ incubation in response to IGFBP-3, butyrate and IGF-I. The inhibitors were added to the incubation medium at final concentrations of $10 \mu \mathrm{M}$ and $50 \mathrm{nM}$ respectively.

\section{Statistical analysis}

The data were analysed using the Stats Direct Biostatistics package (Camcode, Ashwell, Herts, UK). The Wilcoxon test was used for comparison of mRNA expression between paired normal and malignant samples and the Mann-Whitney $U$ test for cell proliferation studies. The chi-squared test was used for comparison of the number of samples with detectable expression in the normal colon and carcinomas. Fisher's exact test was used where expected values were less than 5 . Spearman rank correlation was used for comparison between members of the IGF-I axis. A $P$ value of $<0.05$ was taken as statistically significant. 

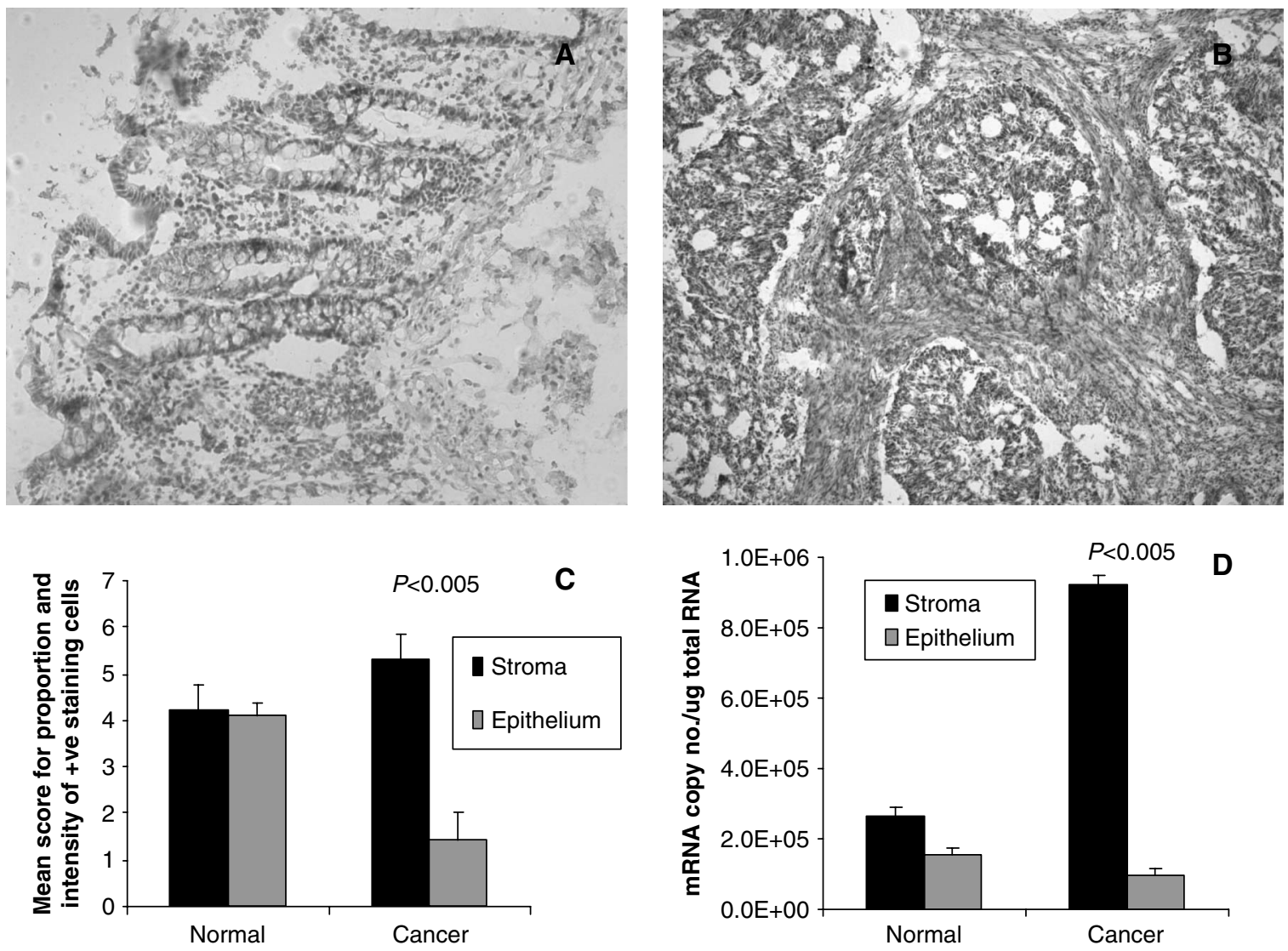

Figure 1 Immunohistochemistry against IGFBP-3 protein expression in a representative section of colonic tissue: (A) normal colon, (B) colonic cancer, (C) mean scores of all samples for proportion and intensity of positive-staining cells in stroma and epithelium and (D) mean \pm S.E.M of 12 per group. IGFBP-3 mRNA copy number/ $\mu \mathrm{g}$ total RNA in stroma and epithelium obtained from laser-captured microscopy.

\section{Results}

\section{Expression of IGFBP-3 mRNA in normal and malignant colon}

IGFBP-3 mRNA was detected in all samples. Median copy number was higher in the malignant samples, $1.3 \times 10^{7}$ (range $2.1 \times 10^{6}$ to $2.0 \times 10^{8}$ ) copy number $/ \mu \mathrm{g}$ total RNA compared with the normal colon samples, $2.6 \times 10^{6}$ (range $4.8 \times 10^{4}$ to $4.2 \times 10^{7}$ ) copies $/ \mu \mathrm{g}$ total RNA $(P<0.0001)$. A direct comparison of paired normal and malignant samples shows that mRNA levels were higher ( $>3$-fold) in 31 of $46(67 \%)$ tumour samples and lower in 2 of $46(2 \%)$. IGFBP-3 mRNA levels could not be detected in either HT-29 or CaCo-2 cells.

\section{Stromal vs epithelial expression of IGFBP-3}

Expression of IGFBP-3 protein was confirmed by immunocytochemistry. Expression in the normal colon was in both the stroma and epithelial cells (mean score \pm s.E.M. $4.2 \pm 0.5$ and $4.1 \pm 0.6$ respectively), while in the tumours it was predominantly confined to the stromal component with significantly less expression in the epithelium (mean score \pm s.E.M. $5.3 \pm 0.3$ and $1.4 \pm 0.6$ respectively; $P<0.005$; Fig. 1 ). Analysis of extracted RNA from the laser-capture microdissected tissue samples confirmed this differential expression of IGFBP-3 between normal and malignant colon. mRNA levels were approximately equal in the stromal and epithelial components of normal colon, but significantly higher in the stromal component of the cancers compared with the epithelial cells (Fig. 1).

\section{Expression of IGF-I, IGF-IR and GH-R mRNA}

All samples expressed mRNA for receptors for both IGF-I and GH (Table 2). Thirty-one (67\%) normal and $19(41 \%)$ tumour samples expressed IGF-I, but 
Table 2 Median (range) mRNA copy number/ $\mu$ g total RNA of IGF-I, IGF-IR and GH-R in 46 paired samples of normal and malignant human colon and the correlation with IGFBP-3 mRNA levels

\begin{tabular}{|c|c|c|c|c|}
\hline & Normal tissue & $\begin{array}{c}\text { Correlation } \\
\text { with } \\
\text { IGFBP-3 ( } r \text { value) }\end{array}$ & Cancers & $\begin{array}{l}\text { Correlation } \\
\text { with IGFBP-3 } \\
(r \text { value })\end{array}$ \\
\hline IGF-I & $\begin{array}{c}4.7 \times 10^{5} \\
\left(6.9 \times 10^{2}-1.5 \times 10^{7}\right.\end{array}$ & $0.6^{\star \star \star}$ & $\begin{array}{c}2.6 \times 10^{5} \\
\left(1.9 \times 10^{3}-3.4 \times 10^{6}\right)\end{array}$ & n.s. \\
\hline IGF-IR & $\begin{array}{c}6.3 \times 10^{6} \\
\left(1.5 \times 10^{5}-2.5 \times 10^{7}\right)\end{array}$ & $0.44^{\star \star}$ & $\begin{array}{c}1.1 \times 10^{7} \\
\left(3.0 \times 10^{6}-9.5 \times 10^{7}\right)\end{array}$ & n.s. \\
\hline GH-R & $\begin{array}{c}7.4 \times 10^{5} \\
\left(1.2 \times 10^{4}-1.9 \times 10^{7}\right)\end{array}$ & $0.38^{\star}$ & $\begin{array}{c}4.2 \times 10^{5} \\
\left(1.3 \times 10^{3}-1.7 \times 10^{7}\right)\end{array}$ & n.s. \\
\hline
\end{tabular}

${ }^{\star} P<0.05 ;{ }^{\star \star} P<0.005 ;{ }^{* \star \star} P<0.0005$.

with median copy numbers significantly lower than those for IGFBP-3 (Table 2). IGF-I-positive normal samples expressed significantly higher IGFBP-3 levels than IGF-I-negative normal samples $\left(4.3 \times 10^{6}\right.$ vs $8.4 \times 10^{5} ; P<0.02$ ). Overall, there was a significant correlation between IGFBP-3 mRNA levels and those of IGF-I, IGF-IR and GH-R mRNA in normal tissue. In contrast, IGF-I -positive and -negative tumours recorded similar levels of IGFBP-3 mRNA and there was no correlation between IGFBP-3 expression and IGF-I, IGF-IR and GH-R mRNA levels. IGF-I expression was absent from both HT-29 and CaCo-2 cells.

\section{Comparison with clinical phenotype}

There was no association between expression of IGFBP-3 mRNA in the tumours and age of patient, Dukes' staging, Microsatellite instability status, TNM classification, or location (proximal or distal colon).

\section{Effect of IGFBP-3 on cell proliferation and apoptosis}

Incubation with IGFBP-3 alone resulted in a significant decrease in proliferation of $\mathrm{CaCo}-2$ cells compared with medium only at $24 \mathrm{~h}$, but there was no effect on HT-29 cells (Fig. 2ii). Addition of IGF-I to the incubation medium largely relieved the inhibitory effects of IGFBP-3. As expected, butyrate exerted significant anti-proliferative effects on both cell lines, especially at $48 \mathrm{~h}$, but these were markedly enhanced by the concomitant addition of IGFBP-3 (Fig. 2ii). This effect was largely relieved by IGF-I.

Cell morphology suggested that the inhibitory effects of IGFBP-3 were predominantly due to apoptosis, as demonstrated by the small shrunken appearance of the cells, but with intact membranes (Fig. 2iii). This was supported by FACS analysis, which demonstrated IGFBP-3 by itself caused a significant increase in late (PI) apoptosis of $\mathrm{CaCo}-2$ cells compared with medium only, but had no effect on HT-29 cells (Fig. 3). Butyrate alone caused a significant increase in both early (annexin binding) and late apoptosis in both cell lines. This was markedly enhanced by the addition of IGFBP-3. Co-incubation with IGF-I significantly reduced these apoptotic responses, particularly for HT-29 cells, but did not completely prevent them. Interestingly, cell morphology suggested that the proliferative response to IGF-I alone was accompanied by an increase in cell-cell aggregation (Fig. 2iii).

\section{Discussion}

Intestinal epithelial cells form a single layer of laterally adherent cells that are organised into crypts. Stem cells are found towards the base of the crypts and give rise to daughter cells, which cease dividing and differentiate as they migrate towards the top of the crypt. As they approach the lumen of the gut, they undergo apoptosis and are sloughed off. IGFBP-3 is emerging as a key regulator of these processes, both in its role as an IGF-I antagonist and as a potent independent antiproliferative agent where it appears to function by both cell cycle blockade and the induction of apoptosis (Baxter 2001). This study has clarified its expression within the colon: using quantitative RT-PCR analysis it is the first to demonstrate universal but differential expression of IGFBP-3 in human normal and malignant colon. IGFBP-3 mRNA was detected in all samples, with its median mRNA levels significantly higher in cancers compared with paired normal tissue. A 3-fold or greater increase was recorded in nearly $70 \%$ of cancers, whereas significant downregulation was observed in only two cancers.

Our finding of increased IGFBP-3 levels in cancers is initially counter-intuitive given the reported antiproliferative and pro-apoptotic effects of IGFBP-3. 


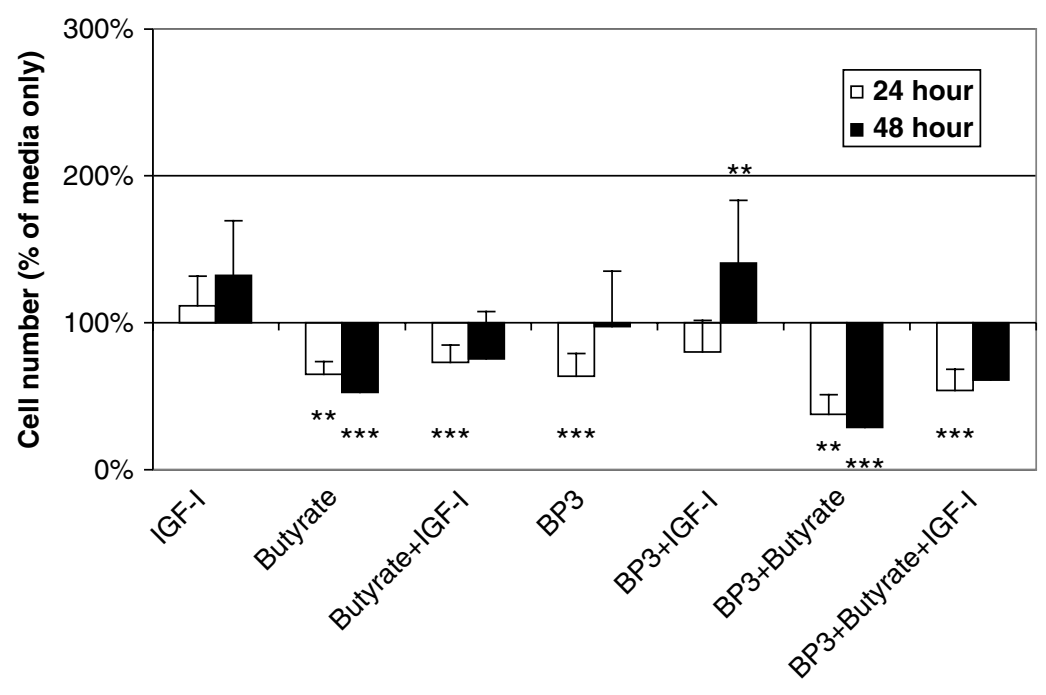

(i)
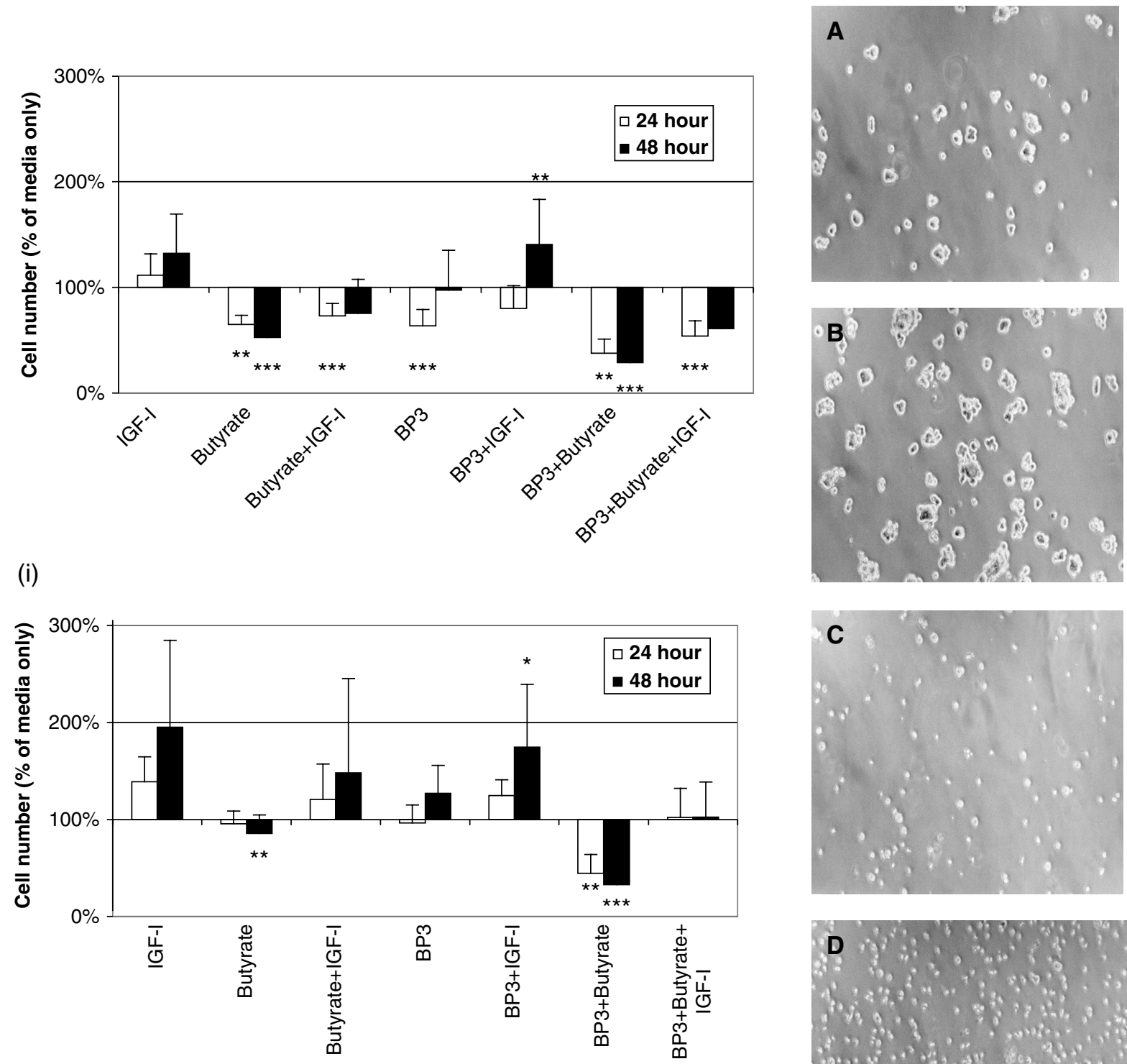

(ii)

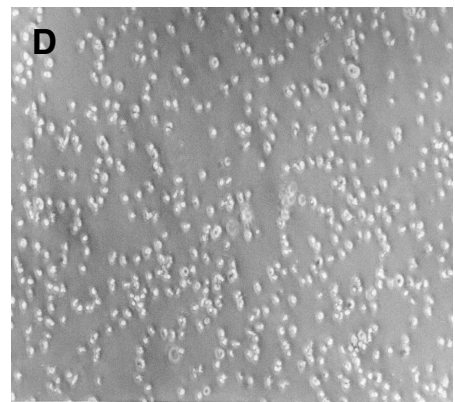

(iii)

Figure 2 Effect of IGFBP-3, IGF-I and sodium butyrate, alone and in combination on (i) CaCo-2 and (ii) HT-29 cell number, assessed by the MTS assay, after 24 and $48 \mathrm{~h}$ incubation compared with medium only; the results are a mean of three experiments with $n=12$; (iii) cell morphology ( $\times 200$ magnification) of CaCo-2 cells incubated with $(A)$ medium only, (B) IGF-I (20 ng/ml),

(C) IGFBP-3 $(200 \mathrm{ng} / \mathrm{ml})$ and (D) IGFBP-3 + sodium butyrate $(5 \mathrm{mM}) .{ }^{\star} P<0.05 ;{ }^{\star \star} P<0.001$; ${ }^{\star \star \star} P<0.0001$.

However, localisation of IGFBP-3 expression within the colonic samples by immunohistochemistry and laser-capture microdissection offers a solution to this paradox. The pattern of expression between normal and cancer tissue is clearly different. In normal tissue,
IGFBP-3 is expressed in both the stroma and the epithelial cells. This is in agreement with a proposed regulatory role for IGFBP-3 on cell proliferation, and its induction by wild-type p53 (Buckbinder et al. 1995). In marked contrast, expression of IGFBP-3 is virtually 
(i) CaCo-2 cells

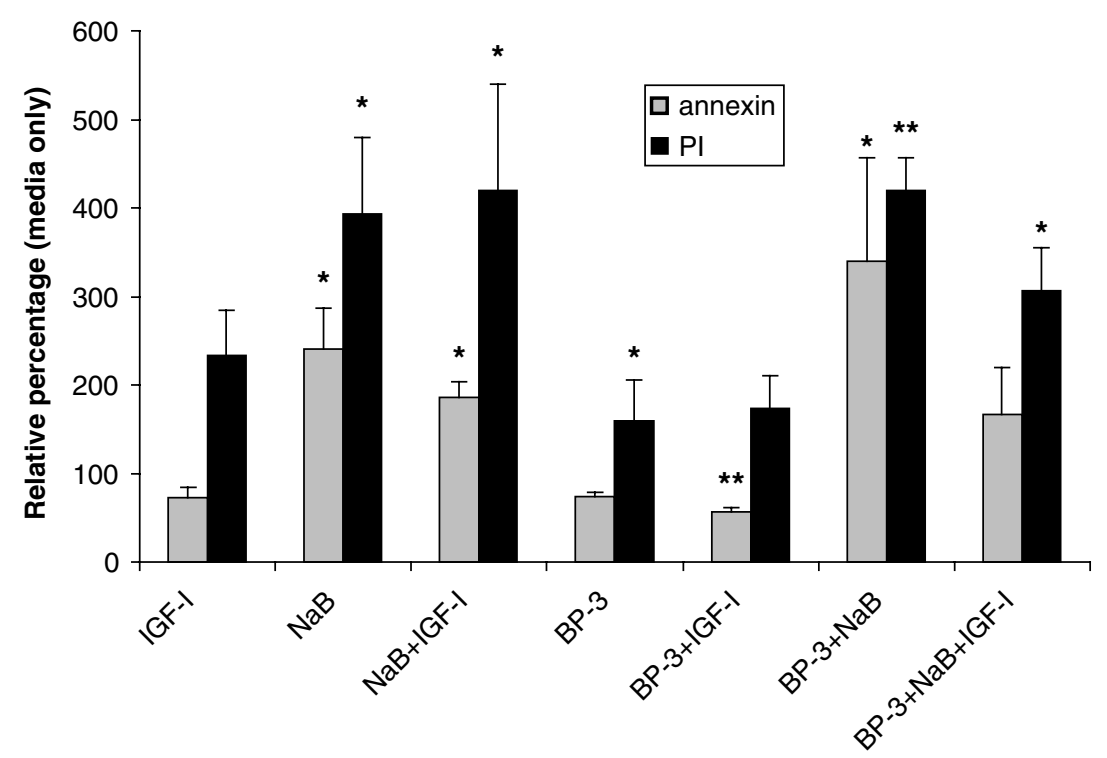

(ii) HT-29 cells

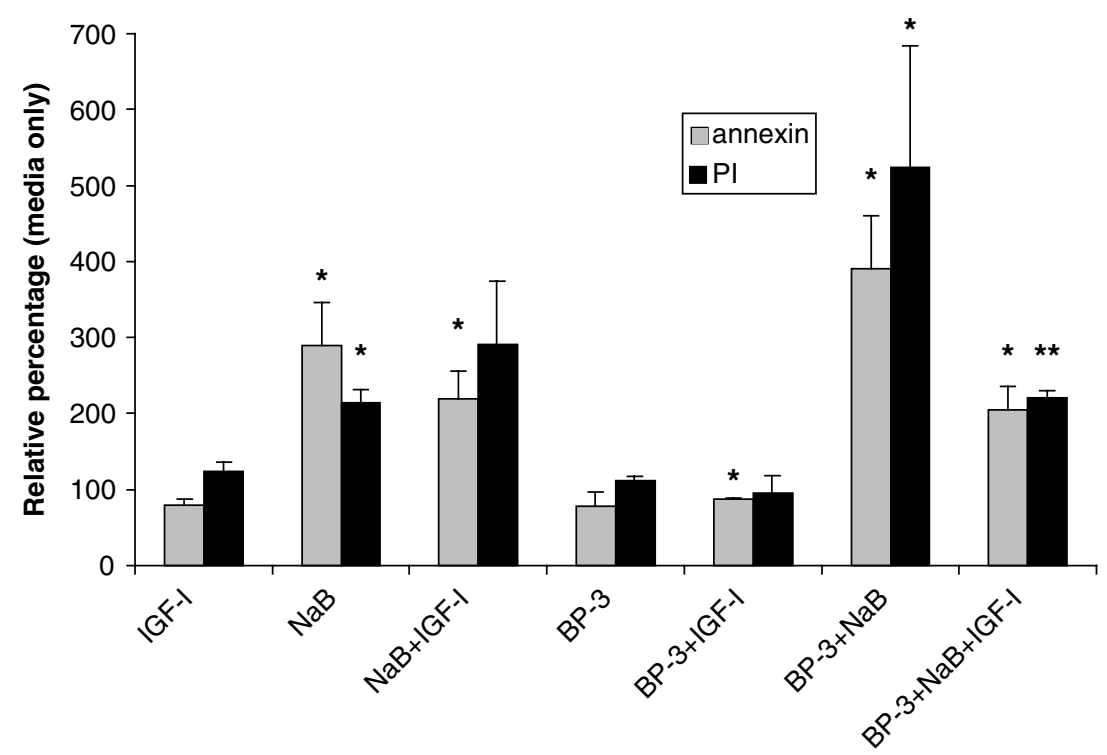

Figure 3 Effects of IGFBP-3, IGF-I and sodium butyrate, alone and in combination on early (annexin binding) and late (PI binding) apoptosis of CaCo-2 and HT-29 cells. Results are means \pm S.E.M. (of three experiments) proportion of apoptotic cells compared with controls (medium only). ${ }^{\star} P<0.05 ;{ }^{\star \star} P<0.001$.

absent from malignant epithelial cells, whereas it is expressed at high levels by the non-malignant stromal component of the tumours. We hypothesise that the marked upregulation of IGFBP-3 expression in the stromal cells of cancers is the result of a physiological response to uncontrolled proliferation of the epithelial cancer cells. The cancer cells themselves have switched off the synthesis of IGFBP-3, and have additionally developed a mechanism to prevent IGFBP-3 protein from diffusing towards them from the stroma. This 
suggests that they may be still responsive to its antiproliferative and apoptotic effects. This theory is supported by our finding that IGFBP-3 mRNA is absent from both HT-29 and CaCo-2 cancer cells, yet they respond appropriately to the anti-proliferative and apoptotic effects of exogenous IGFBP-3. The exact mechanisms responsible for the absence of expression in the cancer component remain undetermined but may involve differences in extracellular matrix, components of which clearly influence IGFBP-3 expression, binding and apoptotic actions (McCaig et al. 2002). The IGF-I axis has also been implicated in the invasion and metastasis of colorectal cancer. These include its direct effects on location, stability and transcriptional activity of $\beta$-catenin (Playford et al. 2000) and the increase in IGF-I bioavailability through the proteolysis of IGFBP-3 by matrix metalloproteinase-19 (Sadowski et al. 2003).

A previous study using northern blot analysis detected IGFBP-3 mRNA in only five of ten cancers; however, this technique is significantly less sensitive than real-time RT-PCR. Two previous studies report in vivo expression of IGFBP-3 protein in colon cancers. The first recorded expression in seven out of ten cancers but no details were given as to its localisation (Michell et al. 1997). The second study reported that in normal tissue the predominant expression was in the epithelial cells, while in cancers it was predominantly maintained in the differentiated epithelial cells (Williams et al. 2000), with some expression in the stroma. Our results agree with the predominant expression of IGFBP-3 in normal epithelium, while in cancers they show that IGFBP-3 expression is virtually exclusive to the stromal component. The reason for this discrepancy is not clear, although it may relate to the known correlation between IGFBP-3 expression and $\mathrm{p} 53$ status of the studied tissue (Buckbinder et al. 1995, Collard et al. 2003). Wild-type p53 is present in differentiated cells but lost in malignant cells.

Our studies have also clarified the function of this local expression of IGFBP-3. It is now well established that IGFBP-3 exerts both IGF-I -dependent and -independent effects on cell proliferation and apoptosis (Baxter et al. 2000). It is probable that some local IGFBP-3 in the colon is involved in modulating the activity of IGF-I at a tissue level and a linkage between the regulation of expression of both genes is suggested by our finding of significantly less IGFBP-3 mRNA in the IGF-I negative samples and a significant correlation between the mRNA expression of both genes. However, the expression of IGFBP-3 mRNA and protein in the absence of local IGF-I in $60 \%$ of our colon cancers also suggests an IGF-I-independent role for the colonic IGFBP-3 gene product. In order to confirm these effects we used HT-29 and CaCo-2 cells, neither of which express IGF-I, and incubated the cells in medium lacking this peptide. The possibility of residual IGF-I activity was excluded by washing the cells and incubation for $24 \mathrm{~h}$ before adding the peptide. IGFBP-3 on its own exerted modest apoptotic actions in $\mathrm{CaCo}-2$ cells, in contrast to a previous study using an adenoma cell line, which failed to show an effect (Williams et al. 2000). This difference may be explained by either a physiological difference between the different cell lines or the higher dose of IGFBP-3 which we used. A dose-dependent effect of IGFBP-3 has also been reported in breast and prostate cancer cell lines (Nickerson et al. 1997, Rajah et al. 1997). What is clear is that IGFBP-3 markedly enhances the apoptosis of colonic epithelial cells in response to sodium butyrate, a known differentiating and apoptotic agent for colorectal cancer cells. A similar enhancement by IGFBP-3 of irradiation-induced apoptosis of colonic epithelial cells was previously reported and shown to be p53-dependent (Williams et al. 2000). The mechanisms underlying our results are likely to be different, as neither HT-29 or CaCo-2 cells express wild-type p53. While this suggests p53 independence, we cannot exclude some contribution by the mutant p53 gene in these cells. However, other studies using different tissues have shown pro-apoptotic p53-independent effects by IGFBP-3 (Rajah et al. 1997, Butt et al. 2000). This influence of $\mathrm{p} 53$ status has also been confirmed in the colon with IGFBP-3 expression occurring in adenoma cells expressing wild-type p53 but absent or very low in p53 mutant cancer epithelial cells (Collard et al. 2003). Our in vitro and in vivo findings agree with this as IGFBP-3 expression was absent in both cell lines and the p53 mutant malignant epithelial cells from the cancer tissues but present in the normal epithelial samples containing wild-type $\mathrm{p} 53$. This correlation with $\mathrm{p} 53$ status may have important therapeutic implications, as administration of IGFBP-3 to malignant p53 mutant cells may enhance the p53-independent apoptotic responses to chemotherapeutic agents, while having no effect on normal cells. Such a differential effect has been reported in breast cancer cells (McCaig et al. 2002).

In conclusion, these findings suggest an important paracrine role of IGFBP-3 in mediating colonic tissue homeostasis and a clear difference between normal and malignant tissue. The pro-apoptotic effects of IGFBP-3 also help explain some of the recent epidemiological studies linking low levels of IGFBP-3 coupled with high IGF-I levels in the colon to a higher risk of colorectal cancer (Giovannucci et al. 2000, 
Palmqvist et al. 2002). Finally, strategies to increase cellular expression of IGFBP-3 may offer the opportunity of a novel powerful adjunctive therapy for colorectal cancer.

\section{Acknowledgements}

This work was supported by grants from Bowel \& Cancer Research and from the Joint Research Board and Cancer Research Committee of St Bartholomew's Hospital. In addition, PJ J is supported by an unrestricted grant from Pfizer UK for research into growth hormone and growth factors. The authors are grateful for the assistance of Professor S Dorudi in the obtaining of surgical samples. The authors declare that there is no conflict of interest that would prejudice the impartiality of this scientific work.

\section{References}

Baxter RC 2001 Signalling pathways involved in antiproliferative effects of IGFBP-3: a review. Molecular Pathology 54 145-148.

Baxter RC, Butt AJ, Schedlich LJ \& Martin JL 2000 Antiproliferative and pro-apoptotic activities of insulin-like growth factor-binding protein-3. Growth Hormone and IGF Research 10 (Suppl A) S10-S11.

Buckbinder L, Talbott R, Velasco-Miguel S, Takenaka I, Faha B, Seizinger BR \& Kley N 1995 Induction of the growth inhibitor IGF-binding protein 3 by $\mathrm{p} 53$. Nature 377 646-649.

Bustin SA 2000 Absolute quantification of mRNA using real-time reverse transcription polymerase chain reaction assays. Journal of Molecular Endocrinology 25 169-193.

Bustin SA, Gyselman VG, Williams NS \& Dorudi S 1999 Detection of cytokeratins 19/20 and guanylyl cyclase C in peripheral blood of colorectal cancer patients. British Journal of Cancer 79 1813-1820.

Bustin SA, Dorudi S, Phillips SM, Feakins RM \& Jenkins PJ 2002 Local expression of insulin-like growth factor-I affects angiogenesis in colorectal cancer. Tumour Biology 23 130-138.

Butt AJ, Firth SM, King MA \& Baxter RC 2000 Insulin-like growth factor-binding protein-3 modulates expression of Bax and $\mathrm{Bcl}-2$ and potentiates $\mathrm{p} 53$-independent radiationinduced apoptosis in human breast cancer cells. Journal of Biological Chemistry 275 39174-39181.

Collard TJ, Guy M, Butt AJ, Perks CM, Holly JM, Paraskeva C \& Williams AC 2003 Transcriptional upregulation of the insulin-like growth factor binding protein IGFBP-3 by sodium butyrate increases IGF-independent apoptosis in human colonic adenoma-derived epithelial cells. Carcinogenesis $\mathbf{2 4}$ 393-401.

Gill ZP, Perks CM, Newcomb PV \& Holly JM 1997 Insulin-like growth factor-binding protein (IGFBP-3) predisposes breast cancer cells to programmed cell death in a non-IGF-dependent manner. Journal of Biological Chemistry 272 25602-25607.

Giovannucci E, Pollak MN, Platz EA, Willett WC, Stampfer MJ, Majeed N, Colditz GA, Speizer FE \& Hankinson SE 2000 A prospective study of plasma insulin-like growth factor-1 and binding protein-3 and risk of colorectal neoplasia in women. Cancer Epidemiology, Biomarkers and Prevention 9 345-349.

Gong J, Traganos F \& Darzynkiewicz Z 1994 A selective procedure for DNA extraction from apoptotic cells applicable for gel electrophoresis and flow cytometry. Analytical Biochemistry 218 314-319.

Le Roith D, Bondy C, Yakar S, Liu JL \& Butler A 2001 The somatomedin hypothesis: 2001. Endocrine Reviews 22 53-74.

Ma J, Pollak M, Giovannucci E, Chan JM, Tao Y, Hennekens CH \& Stampfer M 1999 Prospective study of colorectal cancer risk in men and plasma levels of insulin like growth factor (IGF)-1 and IGF-binding protein-3. Journal of the National Cancer Institute 91 620-625.

McCaig C, Perks CM \& Holly JM 2002 Intrinsic actions of IGFBP-3 and IGFBP-5 on Hs578T breast cancer epithelial cells: inhibition or accentuation of attachment and survival is dependent upon the presence of fibronectin. Journal of Cell Science 115 4293-4303.

Michell NP, Langman MJ \& Eggo MC 1997 Insulin-like growth factors and their binding proteins in human colonocytes: preferential degradation of insulin-like growth factor binding protein 2 in colonic cancers. British Journal of Cancer 76 60-66.

Miraki-Moud F, Jenkins PJ, Fairclough PD, Jordan S, Bustin SA, Jones AM, Lowe DG, Monson JP, Grossman AB, Besser GM, et al. 2001 Increased levels of insulin-like growth factor binding protein-2 in sera and tumours from patients with colonic neoplasia with and without acromegaly. Clinical Endocrinology 54 499-508.

Nickerson T, Huynh H \& Pollak M 1997 Insulin-like growth factor binding protein-3 induces apoptosis in MCF7 breast cancer cells. Biochemical and Biophysical Research Communications 237 690-693.

Oh Y 1997 IGFBPs and neoplastic models. New concepts for roles of IGFBPs in regulation of cancer cell growth. Endocrine 7 111-113.

Palmqvist R, Hallmans G, Rinaldi S, Biessy C, Stenling R, Riboli E \& Kaaks R 2002 Plasma insulin-like growth factor 1, insulin-like growth factor binding protein 3 , and risk of colorectal cancer: a prospective study in northern Sweden. Gut 50 642-646.

Playford MP, Bicknell D, Bodmer WF \& Macaulay VM 2000 Insulin-like growth factor 1 regulates the location, stability, and transcriptional activity of beta-catenin. PNAS 97 12103-12108.

Rajah R, Valentinis B \& Cohen P 1997 Insulin-like growth factor (IGF)-binding protein-3 induces apoptosis and mediates the effects of transforming growth factor-betal 
on programmed cell death through a p53- and IGFindependent mechanism. Journal of Biological Chemistry 272 12181-12188.

Renehan AG, Zwahlen M, Minder C, O'Dwyer ST, Shalet SM \& Egger M 2004 Insulin-like growth factor (IGF)-I, IGF binding protein-3, and cancer risk: systematic review and meta-regression analysis. Lancet 363 1346-1353.

Sadowski T, Dietrich S, Koschinsky F \& Sedlacek R 2003 Matrix metalloproteinase 19 regulates insulin-like growth factor-mediated proliferation, migration, and adhesion in human keratinocytes through proteolysis of insulin-like growth factor binding protein-3. Molecular Biology of the Cell 14 4569-4580.

Vermes I, Haanen C, Steffens-Nakken H \& Reutelingsperger C 1995 A novel assay for apoptosis. Flow cytometric detection of phosphatidylserine expression on early apoptotic cells using fluorescein labelled annexin V. Journal of Immunological Methods 184 39-51.

Williams AC, Collard TJ, Perks CM, Newcomb P, Moorghen M, Holly JM \& Paraskeva C 2000 Increased p53-dependent apoptosis by the insulin-like growth factor binding protein IGFBP-3 in human colonic adenoma-derived cells. Cancer Research $6022-27$. 
